\title{
The Effect of the Global Financial Crisis on Earning Management in Tehran Stock Exchange (Evidence From of the Products of Petroleum and Chemical Industry)
}

Rezaei $\mathbf{M}^{1 *}$ and Neghabi $\mathrm{ZH}^{2}$

${ }^{1}$ Department of Management, Islamshahr Branch, Islamic Azad University, Islamshahr, Iran

${ }^{2}$ Faculty member of Islamshahr, Azad Islamic University, Islamshahr, Iran

\begin{abstract}
The purpose of this study is to investigate the effect of the global financial crisis on earnings management of listed companies in Tehran Stock Exchange and as evidence from of the products of petroleum and chemical industry. The present study is a descriptive-correlation research based on the nature of the data, a quantitative and an applied research based on the goals. Statistical population of this research were active companies in the field of petroleum and chemical listed in Tehran Stock Exchange in the period from 2008 to 2012 and Due to being limited the statistical population, purposive sampling method was used and twenty eight active companies in field of petroleum petrochemicals were selected as sample. In order to illustrate the explanatory power of explanatory variables, the adjusted coefficient of determination was used and in order to examine the significance of variables and the overall adequacy of model, t-statistic and the F-statistic Fisher were used respectively. Also, Statistical analysis was performed using Excel and E-views software's. The results of this study showed that there is a significant relationship between the size of the company and the management of profit in the global financial crisis. There is a significant relationship between profitability index of company and earnings management in the global financial crisis. There is a significant relationship between sale growth and profit management in global financial crises.
\end{abstract}

Keywords: Financial crisis; Earnings management; Companies size; Sales growth; Profitability

\section{Introduction}

Earning management is one of the controversial and attractive issues in accounting researches. Since investors pay attention particularly to amount of profit as one of the most important factors in making decision, this study is important from the behavioral aspect. Studies have shown that low and stable fluctuation of earning is an indication of its quality. As such, investors invest by more confidence, in stocks of companies that their process of profits is more stable. When companies are under increasing pressure and in unfavorable economic conditions, their managers request accounting unit to improve the last line of financial statements (i.e. profit), and thereby alter its information content.

The required data for decision-making is a very complex issue because its diverse range of users, such as investors (since you need to know the profitability and stability of the company before investing in it), managers (need for knowledge of their company's financial situation), banks and funders (the need to inform the company's ability to repay the loan) require various information [1-3]. Of course, one of the main objectives of accounting standards is that users be able to rely on the financial statements related to good and right decisions. Therefore, the accounting profession needs a way of reporting that is desirable and the interests and profits of all users are maintained. On the other hand, in order to achieve certain goals that provide reasonably certain interest groups, managers may report profits in a way that is inconsistent with the purpose of providing general interest users. Auditors have a duty to verify financial statements by evaluating compliance of financial statements with framework outlined in the accounting standards [4,5]. However, the available flexibility in accounting standards is also emphasized on the professional judgment of accountants in some cases for the choice of accounting method. In fact, the problem is derived from that the earnings management, in some cases, leads to financial statements misleading. Whereas these financial statements have no problems from view point of being place in accounting standards framework and auditors cannot criticize financial statements [6]. When companies are under increasing pressure and in unfavorable economic conditions, their managers request accounting unit to improve the last line of financial statements (i.e. profit), and thereby alter its information content [7,8]. Accounting, despite all of its financial flexibility, does not seems to be able to provide useful data for management are in such conditions. The required data for decisionmaking is a very complex issue because its diverse range of users, such as investors (since you need to know the profitability and stability of the company before investing in it), managers (need for knowledge of their company's financial situation), banks and funders (the need to inform the company's ability to repay the loan) require various information $[9,10]$.

One of the methods that is sometimes used in order to arrangement informing of optimal situation of the company, is Earning management [11]. Earnings management refers to public intervention of the management in the process of determining profit that is often along with desired goals of management. Profit management is the method that is used in order to manipulate data by management $[12,13]$. For example, smoothing profits to ensure the sustainability of more profits of investments is an example of manipulating data. Such actions may

*Corresponding author: Mehdi Rezaei, Department of Management, Islamshahr Branch, Islamic Azad University, Islamshahr, Iran, Tel: +982147911; E-mail: rezaiimehdi65@gmail.com

Received July 22, 2016; Accepted August 12, 2016; Published August 22, 2016

Citation: Rezaei M, Neghabi ZH (2016) The Effect of the Global Financial Crisis on Earning Management in Tehran Stock Exchange (Evidence From of the Products of Petroleum and Chemical Industry). J Bus Fin Aff 5: 213. doi: 10.4172/2167. 0234.1000213

Copyright: $\odot 2016$ Rezaei M, et al. This is an open-access article distributed under the terms of the Creative Commons Attribution License, which permits unrestricted use, distribution, and reproduction in any medium, provided the original author and source are credited. 
be significantly affected in the financial statements. There are several ways by which the registered office can be misused in order to manage earnings.

At the most time, illicit records are misused in accounting offices in order to cover up the abuse of financial, in other cases; the records can be misused as a tool to manage earnings [14]. While managing earning, management of the company knows clearly that the goal is to protect the interests of company against the owners of even in other cases. Earning management if for getting the allocated reward due to the maintain the company against profit owners [15].

In fact, what we're looking is the impact of the global financial crisis on earnings management of listed companies in Tehran Stock Exchange (our case study is petroleum products and chemical industry)

It seems that the answer to this question can be very effective for managers and outside investors, companies and potential institutional and independent auditors. Because knowing each one of earning management factors" it will be simpler to prevent earning management specially companies managers.

Therefore, according to the importance of earning and its high information content, usually, managers seek to pursue specific purposes, to manipulate amount of reported earnings. The main problem is that why managers want to manipulate earnings, how to manage their benefits and what are consequences of such behavior?

\section{Review of the Literature}

Gonzalez and Garcia-Meca examined the impact of corporate governance on earning management in Latin American markets [16].

The aim of this study is to investigate the relationship between internal mechanisms of corporate governance and earning management. In this study, to measure earnings management, discretionary accruals were used [17]. Also, in this study, sample of non-financial companies of Latin America during the period from 2006 to 2009 were used.

The analysis results showed that there is a non-linear relationship between local ownership and discretionary accruals. Also, Improvement of the effectiveness of corporate governance leads to reduced earning management.

Cormieret al. investigated the impact of corporate governance on earnings management in the initial public offering companies [18].

Previous research has proposed that managers should use earnings management in order to predict profit voluntary. In this study, we examine earnings management conducted in the initial public offering Canada and investigate which companies use better corporate governance system of earnings management in order to achieve their earnings forecast.

The analysis results show that companies that have better predictive of corporate governance, pay less attention to voluntarily prediction in the initial public offering.

Iqbal and Strong examined the impact of corporate governance on earning management in England companies. In this study, the effect of the structure of the board of directors, ownership structure, counselor's structure and capital structure on discretionary accruals are measured that are as an indicator of earnings management [19].

According to this study, the analysis results indicate that the higher the debt-to-equity ratio leads to more misuse earning of companies.
Companies are more probable to use precautionary Engagement items for income manipulation.

Mahdavi et al. examined the impact of corporate governance on the quality characteristics of the profits anticipated by the management of listed companies in Tehran Stock Exchange's earnings forecast and concluded that its impact on economic decisions of investors is very important. Many studies were conducted on earnings quality expected by management and identify factors affecting on it. In this study, the effect of corporate governance characteristics on the quality of earnings forecast has been reviewed by management $[20,21]$.

Features of the board, institutional shareholders variables and the Audit Committee have been used in order to assess corporate governance. Also, in order to measure the quality of earnings forecast, two variables called accuracy and bias of management in earning predicted were used. Statistical sample was consisted of 100 companies listed in the Stock Exchange during the years 2005 to 2009 [22].

The results of this study show that corporate governance variables have no affect on quality of earnings expected by management of the company accepted in the Tehran Stock Exchange.

Mousavi et al. examined the relationship between earning forecasted errors by management and corporate governance structure in listed companies in Tehran Stock Exchange during 2004 to 2007 [23].

It should be noted that the structure of corporate governance in this study are included: Percentage of ownership of board members, bound board members, and the board of the board risk of director.

Volume of statistical population was consisted of 363 member companies of Tehran Stock Exchange that 146 companies during the period 2004 to 2008 have been selected due to the limitations of the study.

In order to provide the literature of this study, information contained in the financial statements of companies, software Tadbir Pardaz, Library of Exchange organization, and archive of sites of Stock Exchange were used [24]. Pearson correlation coefficient and multiple linear regression model were used in order to test hypothesizes. The results of this study show that there is a positive relationship between the percentage of ownership of board members, board members and members of the board of directors and the accuracy of earnings forecasted. There is a negative relationship between the risk-management earnings and prediction of earning of management. Testing hypothesizes showed that all hypothesizes are confirmed.

\section{Methodology}

This study uses retrospective approach. On the other hand, this study is descriptive-correlation research. Based on the nature of the data, the type of this study is quantities'. This study is application one based on objectives. In order to examine hypotheses of our study and according to the nature of information and research data, information is quantities'.

\section{Method and data collecting tools}

Information and data required for this study were collected by using two methods:

1. The information related to this study is theoretical one and from various references such as books and magazines that internationally are available online at sites collected. 
2. Raw information and data required in order to verify the hypothesis results were collected through innovative software, processor and necessary measure was collected through direct reference of the Company's financial statements as CD by the Stock Exchange Tehran and the website of this organization.

3. Company financial statements, including balance sheet, income statement, and cash flow statement and notes accompanying the financial statements at the end of each financial year is used as a research tool.

4. In this study, in order to estimate the parameters of descriptive statistics and statistical models in research and analysis and statistical inference, E-views and Excel software are used.

\section{The regression model of study}

Earning Management ${ }_{i t}=a_{0}+a_{1}$ Size $_{i t}+a_{2}$ Growth $_{i 1}+a_{3}$ Profitable $_{i t}+a_{4}$ Levearge $_{i t}+a_{5}$ Industry $_{i+}+\varepsilon$

\section{Method of analyzing data}

Statistics are discussed as descriptive statistics, probability and inferential statistics. Probability and probability theory are essentially outside the scope of our discussion. Also descriptive statistics such as frequency, mean, variance and assumptions were considered $[25,26]$.

In this study, the combined data is used in order to test the hypotheses. In this way, time series data (the years studied) and sectional (companies surveyed) are combined. Combined data are used to increase amount of observations, raise degrees of freedom, decrease heterogeneity of variance and dynamic of the changes.

In order to estimate the effectiveness of a regression model using compound data, one of the common effects models, fixed effects and random effects using appropriate tests are selected.

First, in order to determine whether the time series xt static (agglomeration time zero) or divergent process (Agglomeration time), we use the Lin and Levine test $[27,28]$.

Similar to study on static variables, here, we also require proper methods for combined data. We use the modified Wald test in order to evaluate heterogeneity of group among remaining of fixed effects regression model. Also, we use two tests F-test and Hausman test in order to determine the effect of fixed or random effects.

To illustrate the explanatory power of explanatory variables adjusted coefficient of determination (Adjusted R2) to investigate the significance of variables and $\mathrm{t}$-statistic to assess the overall adequacy of the F-statistic model Fisher were used. The statistical analysis using software, EXCEL and EVIEWS 7 will be carried out.

\section{The study variables}

Dependent variable: This is variable that is not measured, manipulated and selected by the researcher, and we attempt to find their relationship with the dependent variable by evaluating each of the independent variables.

In this study, earnings management is the dependent variable.

Independent variable: It is variable that is measured by the researcher manipulated or selected to influence or determine its association with other variables.

In this study, company size, sales growth and profitability indicators are independent variables.
Control variable: Because of all the variables in the study cannot be examined, researcher neutralizes effects of some variables through statistical control or the research control. The variables whose effects are removable by researcher are called control variable. Financial leverage and efficiency of assets are control variables.

\section{Hypothesis testing}

\section{First hypothesis testing}

H0: there is no significant relationship between firm size and earnings management in the global financial crisis.

H1: there is a significant relationship between firm size and earnings management in the global financial crisis.

- According to Table 1, since the Durbin-Watson test statistic is placed at a distance of 1.5 to 2.5 , assuming correlation between errors is not rejected and regression can be used.

Due to the significance of the test F (34.158) at the level of error smaller than 0.01 , it can be concluded that the research regression model consisting of independent variables, control and dependent, independent and control variables can set a good model and explain profit management changes. Amount of coefficient of determination is 0.555 , indicating that $55.5 \%$ of the total variation of the dependent variable, and is dependent to independent and control variables in the model. Impact factor of company size variable on earnings management is 3.559 that means that a direct and positive impact earnings management.

According to the significant level of t-statistic, variable of company size on earning management (0.015), due to being lower than $5 \%$ error level, we can reject $\mathrm{H} 0$ hypothesis by $95 \%$ confidence and state that there is a significant relationship between company size and earnings management during the global financial crisis.

The research model is as follows:

Earning Management $\mathrm{it}_{\mathrm{it}}=0.482+3.559$ Size $_{\mathrm{it}}+0.515$ Levearge $_{\mathrm{it}}+0.796$ Industry $_{\mathrm{it}}+\varepsilon_{\mathrm{it}}$

\section{Testing second hypothesis}

H0: there is no significant relationship between sales growth and earnings management in the global financial crisis.

H1: there is a significant relationship between sales growth and earnings management in the global financial crisis.

According to Table 2, since the Durbin-Watson test statistic is placed at a distance of 1.5 to 2.5 , assuming no correlation between errors is not rejected and regression can be used. According to the significance of the test F (43.059) at the level of error smaller than 0.01 , it can be concluded that the research regression model consisting

\begin{tabular}{|l|l|l|l|l|}
\hline $\begin{array}{l}\text { Significance } \\
\text { level }\end{array}$ & t-score & $\begin{array}{l}\text { Estimate } \\
\text { deviation }\end{array}$ & $\begin{array}{l}\text { Coefficient } \\
\text { deviation }\end{array}$ & Variable \\
\hline $0.021^{*}$ & 3.651 & 0.132 & 0.482 & Fix \\
\hline $0.015^{\star}$ & 4.611 & 0.772 & 3.559 & Company size \\
\hline $0.026^{\star}$ & 3.083 & 0.167 & 0.515 & Financial leverage \\
\hline $0.019^{\star}$ & 3.882 & 0.205 & 0.796 & Industry type \\
\hline 2.318 & & Camera-Watson & \\
\hline 34.158 & F-score & \\
\hline $0.000^{\star *}$ & & Significance level \\
\hline 0.555 & & Modified coefficient determination \\
\hline
\end{tabular}

* $5 \%$ error and $1 \%$ error**

Table 1: Regression and model significance. 


\begin{tabular}{|l|l|l|l|l|}
\hline $\begin{array}{l}\text { Significance } \\
\text { level }\end{array}$ & t-score & $\begin{array}{l}\text { Estimate } \\
\text { deviation }\end{array}$ & $\begin{array}{l}\text { Coefficient } \\
\text { deviation }\end{array}$ & Variable \\
\hline $0.014^{*}$ & 4.239 & 0.117 & 0.496 & Fix \\
\hline $0.021^{*}$ & -3.258 & 0.236 & -0.767 & Company's selling growth \\
\hline $0.026^{*}$ & 3.962 & 0.134 & 0.531 & Financial leverage \\
\hline $0.018^{*}$ & 4.517 & 0.159 & 0.718 & Industry type \\
\hline 1.714 & & Camera-Watson & \\
\hline 43.059 & & F-score & \\
\hline $0.000^{* *}$ & & Significance level \\
\hline 0.667 & & Modified coefficient determination \\
\hline
\end{tabular}

*5\% error and $1 \%$ error** $^{*}$

Table 2: Regression and model significance test.

\begin{tabular}{|l|l|l|l|l|}
\hline $\begin{array}{l}\text { Significance } \\
\text { level }\end{array}$ & t-score & $\begin{array}{l}\text { Estimate } \\
\text { deviation }\end{array}$ & $\begin{array}{l}\text { Coefficient } \\
\text { deviation }\end{array}$ & Variable \\
\hline $0.029^{*}$ & 3.736 & 0.114 & 0.426 & Fix \\
\hline $0.038^{*}$ & -3.021 & 0.186 & -0.562 & Index of profitability \\
\hline $0.032^{*}$ & 3.324 & 0.253 & 0.841 & Financial leverage \\
\hline $0.035^{\star}$ & 3.242 & 0.107 & 0.347 & Industry type \\
\hline 1.803 & & Camera-Watson & \\
\hline 36.492 & & F-score & \\
\hline $0.000^{\star *}$ & & Significance level \\
\hline 0.483 & & Modified coefficient determination \\
\hline
\end{tabular}

${ }^{*} 5 \%$ error and $1 \%$ error** $^{*}$

Table 3: Regression and model significance test.

of independent variables, control and dependent, independent and control variables can set a good model and explain profit management changes.

Amount of coefficient of determination is 0.667 , indicating that $66.7 \%$ of the total variation of the dependent variable is dependent to independent and control variables in the model. Coefficient of effect of sales growth over the earning management is -0.767 , which reflects the negative impact on earnings management sales growth of companies. According to the significance level of the t-statistic of sales growth variable on earnings management (0.021), due to being lower than the $5 \%$ error level, H0 hypothesis can be rejected with $95 \%$ confidence. It can be said that there is a significant relationship between the growth of sales and earnings management in the global financial crisis.

The research model is as follows:

Earning Management ${ }_{\mathrm{it}}=0.496-0.767$ Growth $_{\mathrm{it}}+0.531$ Levearge $_{\mathrm{it}}+0.718$ Industry $_{\mathrm{it}}+\varepsilon_{\mathrm{it}}$

\section{Testing third hypothesis}

$\mathrm{H} 0$ : there is no significant relationship between indicators of profitability and earnings management in the global financial crisis.

H1: there is a significant relationship between indicators of profitability and earnings management in the global financial crisis.

According to Table 3, since the Durbin-Watson test statistic is placed at a distance of 1.5 to 2.5 , there is no correlation between errors is rejected and regression can be used.

Due to the significance of the test F (36.492) at the level of error smaller than 0.01 , it can be concluded that the research regression model consisting of independent variables, control and dependent, independent and control variables can set a good model and explain earning management changes.

Amount coefficient of determination is 0.483 , indicating that
$48.3 \%$ of the total variation of the dependent variable is dependent to independent and control variables in the model.

Coefficient of effect of benefits on earnings management is -0.562 , which reflects the negative impact on earnings management is profitability index. Due to the significance level of the t-statistic variable sales growth on earnings management (0.038), due to lower than the $5 \%$ level $\mathrm{H} 0$ hypothesis can be rejected with $95 \%$ and it can be said there is a significant relationship between the index of profitability and earnings management during the global financial crisis.

The research model is as follows:

Earning Management ${ }_{\mathrm{it}}=0.426-0.562$ Profitable $_{\mathrm{it}}+0.841$ Levearge $_{\mathrm{it}}+0.347$ Industry $_{\mathrm{it}}+\varepsilon_{\mathrm{it}}$

\section{Results of Study}

Earnings management in the accounting literature is related to issues that arise in earning of accounting. This issue was formed in accounting from the beginning of the twentieth century and then several investigations were conducted by experts in the field of accounting. Each of these studies evaluated specific dimensions of this issue. Earnings management, because of the stigma of some companies in recent years, is at the forefront of public attention. Earnings management, because of the stigma of some companies in recent years is at the forefront of public attention and decision making authorities have paid more attention to this issue and have made several changes.

The earning is calculated and recognized based on accrual accounting. That is on the basis of income fulfillment based and expense occurrence identification engagement but not received or payment in cash. Therefore, in the calculation and recognition of profit estimates, projections and allocation accounting are used.

Therefore, use of income as a measure of the performance of companies, is an issue with uncertainty, because of the influence of the estimates and accounting methods. While cash flow from operations due to lower management role in the manipulation of those criteria in evaluating the company's performance is more reliable.

\section{Comparison of the results with other studies}

First hypothesis: Result of test Hypothesis showed that there is a significant profit the size of the company and the management of the global financial crisis. This result is no consistent with results Aghaii et al. and in consistent with the results of Akbar et al. [29-33].

So, it can be concluded that bigger companies have more tend to manipulate the profit than other companies within the financial crises.

Second hypothesis: Hypothesis test result showed that there is a significant relationship between the growth in sales and earnings management in the global financial crisis. This result is consistent with other results Mohammad et al. is consistent with the results of Ali et al. [34-39].

For these companies, we can conclude that companies that have higher growth of sales and lower volatility, their earnings management in those is less.

Third hypothesis: Result of testing hypothesis showed that there is a significant relationship between the index of profitability and earnings management during the global financial crisis. This results is not Consisted with the study by some authors [34-38] are consistent and the results does not match [36-39].

Therefore, it can be concluded that the profitability of companies can play a role in reducing the earnings management of Companies 
Citation: Rezaei M, Neghabi ZH (2016) The Effect of the Global Financial Crisis on Earning Management in Tehran Stock Exchange (Evidence From of the Products of Petroleum and Chemical Industry). J Bus Fin Aff 5: 210. doi: 10.4172/2167-0234.1000210

and the managers of these companies do not tend to tamper the profit because of the appropriate profitability.

\section{Proposes of this study}

Internal proposes: It is proposed to investors, shareholders and other interest groups in their decisions to buy and sell shares of a company, in order to ensure the non-profit company can manipulate the size of the company, sales growth and profitability index case terms of attention, since the results of these factors have a significant impact on earnings management in companies. It is also recommended to pay attention board the Audit Committees. In this way, you can monitor the behavior of their management control.

\section{External Suggestions:}

- We recommend evaluating the effect of "ownership structure" in the management of corporate profits paid during the global financial crisis.

- We recommend investigating the effect of "the Board" on the management of corporate profits paid during the global financial crisis.

- We recommend reviewing the impact of the "Audit Committee" on the management of corporate profits paid during the global financial crisis.

- We recommend evaluating evaluate the effect of "liquidity" on the management of corporate profits paid during the global financial crisis.

We recommend evaluating the effect of "risk management" on the management of corporate profits paid during the global financial crisis.

\section{References}

1. Adrian $\mathrm{T}$, Colla $\mathrm{P}$, Shin $\mathrm{H}$ (2012) Which financial friction? Parsing the evidence from the financial crisis of 2007-2009. Staff report, federal reserve bank of New York pp: 1-55.

2. Francis B, Hasan I, Li L (2014) Abnormal real operations, real earnings management and subsequent crashes in stock price. Bank Finland research, discussion papers.

3. Ardekani A, Younesi N, Hashemjijoo M (2012) Acquisition, earnings management and firm's performance: evidence from Malaysia. Journal of business studies quarterly 4: 91-110.

4. Rial S, Tano C (2014) The impact of the global financial crisis on audit quality Master Thesis.

5. Chaiporn V (2014) What explains the initial return of initial public offerings after the 1997 Asian financial crisis? Evidence from Thailand.

6. Xu Y, Carsona E, Fargherb N, Jiang L (2013) Responses by Australian auditors to the global financial crisis. Accounting and finance 53: 303-338.

7. Faiq M, Xia X, Ali M, Usman M, Shahid H (2011) How Asian and global economic crisis prevail in Chinese IPO and stock market efficiency. International business research.

8. Fauzi F, Hewa-Wellalage N, Locke S (2012) The global financial crisis' impact on short-term performance of IPO: the case study of New Zealand firms' IPOs. Asian journal of finance and accounting 4: 180-198.

9. Bloom N (2009) The impact of uncertainty shocks. Econometrica 77: 632-685.

10. Andre D, Dimitrious G (2013) European sovereign debt crisis and the performance of Dutch IPOs. SSRN 30: 308-319.

11. Gholamreza EB, Hashem N, Banimahd F, Mirsepassi N (2011) Check conservatism in the global financial crisis. Knowledge of financial securities analysis.

12. Filip A, Raffournier B (2014) Financial crisis and earnings management. The international journal of accounting 49: 455-478.
13. Armstrong C, Foster G, Taylor D (2008) Earnings management around initial public offerings: A Re-examination. SSRN Electronic Journal.

14. Francis J, Lafond R, Olsson R, Schipper K (2005) The market pricing of accruals quality. Journal of accounting and economics 39: 295-327.

15. Gong G, Louis H, Sun A (2008) Earnings management, lawsuits and stock for-stock acquirers' market performance. Journal of accounting and economics 46: 62-77.

16. Habib A, Adin MB, Islam A (2013) Financial distress, earnings management and market pricing of accruals during the global financial crisis. Managerial Finance 39: 155-180.

17. Ronen J, Yaari V (2008) Earnings management: Emerging insights in theory practice and research. Springer.

18. King E, Banderet L (2014) IPO stock performance and the financial crisis. Stokholm School of economics. Master thesis in finance. SSRN paper.

19. Molik A, Mir M, McLver R, Bepari M (2013) Effects of audit quality on earnings management during the global financial crisis. Proceedings of $9^{\text {th }}$ Asian business research conference pp: 1-27.

20. Kousenidis D, Ladas A, Negakis C (2013) The effects of the European deb crisis on earnings quality. International review of financial analysis 30: 351-362.

21. Razi Z, Gao L, Yu J (2012) Industry peer firms earnings predictably, financial crisis and IPO underpricing. University of Memphis, Memphis pp: 1-55.

22. Richardson S, Sloan R, Soliman M, Tuna I (2005) Accrual reliability, earnings persistence and stock prices. Journal of accounting and economics 39: 437485

23. Richardson G, Taylor G, Lanis R (2015) The impact of Financial distress on corporate tax avoidance spanning the global financial crisis: Evidence from Australia. Journal of banking and finance 52: 112-129.

24. Korteweg A (2007) The costs of financial distress across industries.

25. Wai FW (2013) The initial performance of Malaysia IPOs during the financial crisis: evidence from global financial crisis of 2008. Master of business administration, Universiti Tunku Abdul Rahman, Malaysia pp: 1-54.

26. Ahmadpour, Montazeri A, Hadi (2011) Study on type of earnings management and the impact of company size, ownership structure and corporate governance of accounting advance.

27. Arezzo B, Abbas S, Zanganeh M (2012) Study on Earnings Management in the Time of shares of companies listed in Tehran Stock Exchange. The first regional conference on new approaches in accounting and auditing.

28. Omid P, Ali R, Reza G (2013) examination of the impact of the actua management of profit on the investment behavior of listed companies in Tehran Stock Exchange, accounting developments.

29. Zahra P, Mehdi PR (2012) Study on relationship between earnings management and corporate financial capability. Financial knowledge of the securities 5 : $77-88$

30. Saied JK, Saied K, Akbar PA (2009) Study on relationship between income smoothing and corporate financial distress. Financial Accounting. 1: 60-80

31. Mohsen D, Zadeh H, Vali AK, Ali V (2012) Quality of earnings in financial distress companies. Financial accounting research 4: 1-16.

32. Muhammad ZM (2012) Study on accountants and their role in the recent global financial crisis. The first regional conference on new approaches in accounting and auditing.

33. Ali S, Narges H, Hamed R (2013) The relationship between real earnings management activities and future performance of the listed companies in tehran stock exchange. Management accounting 6: 45-58.

34. Motevassel M, Tohidi F (2012) Evaluation of the financial crisis and the role of accounting and auditing. First regional conference on research and new methods of management and accounting

35. Beata M, Mehrani S, Kaveh M, Creamy GH (2005) Accruals in the management of firms listed in the Tehran Stock Exchange. Review of accounting and auditing 42: $61-74$

36. Ejad N, Sehr S, Karami MN (2005) Study on earnings management in listed companies in Tehran Stock Exchange. Journal of Social Sciences and Humanities. 
Citation: Rezaei M, Neghabi ZH (2016) The Effect of the Global Financial Crisis on Earning Management in Tehran Stock Exchange (Evidence From of the Products of Petroleum and Chemical Industry). J Bus Fin Aff 5: 210. doi: 10.4172/2167-0234.1000210

Page 6 of 6

37. Hashem N, Mahdi T, Hamid AZ (2014) Economic consequences of accounting information quality management with a focus on variable Svd. Accounting stability $7: 1-15$.

38. Hashem V, Talebnia G, Ali J (2013) The effect of earnings management on earnings quality companies with the financial crisis. Accounting knowledge 4 75-103.

39. Frshad H, Vahid Z (2011) Investors' reaction to the news of the financial crisis over Iran's stock market financial Jhany. Dansh securities analysis exchange 4: 75-100. 